JOHNSON, I.M. Staff development in international technical cooperation programmes: the case of the TEMPUS Joint European Project 'LISTEN'. Information Development, 13 (4), December 1997, 197-202. [ISSN 0266-6669] [online]: http://idv.sagepub.com/cgi/reprint/13/4/197 [Accessed 25 June 2008]

(Also translated into Polish by Remigiuz Sapa, and published as: Rozwoj kadr w miedzynarodowych technicznych programach wspolpracy: na przykladzie projecktu LISTEN realizowanego w ramach programu TEMPUS $\underline{i n}$ : Swiatowa strategia edukacji bibliotekarzy i specialistow informacji naukowej [Education of librarians and information professionals: global strategy]; edited by Maria Kocojowa. 1998. Krakow, Poland: Wydawnictwo Uniwersytetu Jagiellonskiego [Jagellonian University Press]. pp. 72 - 85. ISBN 832331109 9)

\title{
STAFF DEVELOPMENT IN INTERNATIONAL TECHNICAL COOPERATION PROGRAMMES: the case of the TEMPUS Joint European Project 'LISTEN'
}

\section{Ian M. Johnson}

School of Information and Media, The Robert Gordon University, Aberdeen AB24 5BN (i.m.johnson@rgu.ac.uk)

\begin{abstract}
The paper explains the relationship between the purposes of staff development in Schools of Librarianship and Information Studies, and of international technical cooperation projects such as those supported by the European Commission's TEMPUS programme. It links this to an evaluation of the staff development from which the Robert Gordon University School of Information and Media has benefited during its involvement in the 'LISTEN' Joint European Project during its three year life (1994-97). It explains the position which the School of Information and Media was in when the planning for this Project commenced about 5 years earlier; outlines the purposes of staff development in the School, and points to those which are intended to develop the individual, and those which are related to the broader needs of the School and the University. It presents an analysis of the aims of international technical cooperation activities, and matches them against the aims of staff development as a framework within which to evaluate the impact on staff development of Project 'LISTEN'. It identifies individual and institutional benefits in terms of staff development, and notes its impact on the profile of the School. Finally, it points to a number of outstanding issues, particularly the need for continuing cooperation after the end of a project; whether technical cooperation activities should be maintained through further institutional leadership or could be led independently by staff who have been effectively developed; and the limited number of Schools engaged in cooperative activities.
\end{abstract}

\section{Introduction}


The conventional perception of international technical cooperation programmes, the perception that is of those who have not been involved, is a mixture of cynicism and envy, coupled with a narrow consideration of the costs and benefits to the institutions involved. Institutional managements' concerns focus on the alleged frivolous nature of these projects and the commitment of expensive staff time. The staff engaged in these projects are almost inevitably engaged in travel between countries, and their professional activity is largely obscured by a belief that they are engaging in tourism at the funding agency's expense. All the benefits are represented as accruing to the partner in the less developed institution, and all the costs are believed to fall directly on the agency funding the project and indirectly on the more developed institution whose staff are deployed on the project. Participating institutions have therefore conventionally expected to recover all or part of their contribution through a direct charge for staff time, or an indirect subsidy through the payment of tuition fees for students recruited from the 'beneficiary' institution or country.

Parker's writings about international consultancy provide a sound picture of the professional challenges involved in technical cooperation projects, and implicitly an effective rebuttal of the tourist image $\mathrm{i}^{\mathrm{i}}$. The purpose of this paper is to examine one of the major non-financial benefits to the institutions involved, to create a better understanding of the benefits and encourage a greater willingness to participate. It outlines the underlying purposes of international technical cooperation programmes, and the aims of staff development in Schools of Librarianship and Information Studies. This provides a framework within which can be identified the staff development from which Schools might benefit as a result of involvement in such projects. It uses a specific project in Hungary as a case study.

Following an introduction to the European Commission's TEMPUS programme and the project 'LISTEN', the paper begins by explaining the position which the School of Information and Media at The Robert Gordon University was in when the planning for this Project commenced about 5 years ago. Next, it outlines the purposes of staff development in the School, in terms of the aims set out in the School's annual staff development report and agreed by the University, pointing to those which are intended to develop the individual, and those which are related to the broader needs of the School and the University. An outline of the aims of technical cooperation programmes is followed by a demonstration of the link between staff development, and technical cooperation projects. Against the background of the activities of Project 'LISTEN', the paper provides an evaluation of the staff development implicit in the Project, its impact on individuals, the University, and the School. Finally, the paper points to a number of issues relating to the continuation of the cooperative activities and future staff development needs.

The paper does not seek to evaluate the development which has taken place in the staff of the Hungarian ${ }^{\text {ii }}$ or other Western partners. However, the processes through which they have gone ${ }^{\text {iii }}$ have probably been of mutual benefit, and most of the observations in the paper appear as relevant to the Hungarian and other Western institutions as to The Robert Gordon

University.

\section{TEMPUS and project 'LISTEN'}

The European Commission established the TEMPUS programme (Trans European Mobility

Programme for University Studies) with the aims of improving the capabilities of higher education institutions through development of teaching staff and support for structural 
improvements. Assistance which can be provided in eligible countries in Central and Eastern Europe and the former Soviet Union through TEMPUS schemes can include:

- Purchase of teaching materials (e.g. books, journals), and equipment (e.g. computers, software)

- Study visits, attendance at courses, and industrial placements in Western Europe for teaching staff and students from the eligible countries

- Study, advisory and teaching visits by staff from Western Europe to the eligible countries

- Replacements for staff engaged in TEMPUS activities

- Linguistic preparation for staff and students

- Translation of teaching materials

With TEMPUS funding, the author had conducted a number of study visits in 1992 and 1993 concerned with the developmental needs of Schools of Librarianship and Information Studies throughout Central and Eastern Europe ${ }^{\text {iv }}$. These included a visit to Hungary ${ }^{\mathrm{v}}$, and concluded in an international workshop in Bratislava in 1994 which secured co-funding from UNESCO's Division of the General Information Programme ${ }^{\text {vi }}$. Subsequently the School was invited to become a partner in the Joint European Project 'LISTEN' with: Berzsenyi College, Szombathely, Hungary; Bessenyei College, Nyiregyhaza, Hungary; Danmarks Biblioteksskole, Copenhagen, Denmark; Fachhochschule fur Bibliotheks- und Informationswesen, Stuttgart, Germany; and De Montfort University, Leicester, U.K. The Royal Danish School of Librarianship acted as the Contractor for the Project, and Berzsenyi College undertook the role of Project Coordinator.

Project 'LISTEN' (Library and Information STudies Education Network), was a three year programme. The European Commission allocated c.400,000 ECU as overall support for the Project during the period from 1994 to 1997. This supported not only the development of the 2 Schools of Librarianship, but also aspects of user education in the Budapest University of Economic Sciences, the College of Finance and Accountancy, Zalaegerszeg, and the University of Veszprem. The principal aims of the project were to:

- improvement of the Information Technology infrastructure, and implementation of relevant applications in the curriculum at the 2 Schools of Librarianship

- preparing University librarians and staff of the Schools to use local, national and international computerised information systems

- designing and introducing business information courses in the Schools and the University libraries

- general development of a modern curriculum in Librarianship and Information Studies

\section{The profile of the School of Information and Media in the early 1990s.}

The Robert Gordon University has recently undertaken a formal evaluation of each of its Schools, as part of the Strategic Change Review initiated by the Scottish Higher Education Funding Council (SHEFC). Within this review, one major activity was an analysis of the School and its portfolio of courses. This included a consideration of the Strengths and Weaknesses of all the courses, and the Opportunities that might be taken to enhance them, as well as the Threats they face from external competition and environmental factors. The recent SWOT evaluation of the School of Information and Media is presented later. In the context of the paper it is perhaps useful to start from the author's evaluation of the then School of Librarianship and Information Studies as it was at the beginning of the 1990s. 
Table 1. Profile of the School in the early 1990s

\section{- Strengths \\ Quality of staff; local recognition \\ - Weaknesses}

Narrow portfolio of courses and employment opportunities for graduates; poor equipment; overteaching; no research; unknown outside Scotland; no collaboration with practitioners or other academic disciplines in research; inappropriate funding for the discipline

\section{- Opportunities}

The emerging 'Information Society'; University support for growth, for staff development and for European integration; student centred learning; government support for research

- Threats

Closure or take-over; development of competing courses

Its principal strength was the quality of its teaching staff. They were hardworking, progressive in their attitudes, skilled in teaching Information Technology applications, and committed to high quality teaching. The School and its staff were well known and well regarded in Scotland. However, its weaknesses were numerous. The course portfolio was narrowly focused on library and information studies; there were no courses in business information despite the fact that the City of Aberdeen has the largest concentration of specialist libraries in the United Kingdom outside London; the equipment resources for teaching Information Technology applications were limited in quantity because of inappropriate funding levels; students were being taught rather than encouraged to learn; there was little research activity; and the School was little known in the rest of the United Kingdom and almost unknown outwith the UK.

In common with many small Schools and Departments in British Universities at the time, not only in librarianship, the School was threatened - because it was small - with the loss of its independent existence. The University had, however, been persuaded that the School was capable of growing and developing. There were indeed many opportunities for the School to develop, arising from the emergence of the Information Society and the need for more information professionals with a range of new skills; government support for the development of higher education; strong institutional support for staff development and for European integration; and changes in government policy which conferred University status on the institution, encouraged more student centred learning, and provided support for research.

The author's first contact with Schools of Librarianship in Hungary had been in May 1988 when he made a visit to Budapest, Gyor and Szombathely to carry out some research. The strengths and weaknesses which he noted in the Hungarian Schools of Librarianship at that time $^{\text {vii }}$ had many parallels in what he was to find when appointed Head of School at the Robert Gordon University later that year. Some of the opportunities available to the Schools in Hungary were also similar. By 1993 when the Royal Danish School of Librarianship began discussions about possible participation in the project, the School of Information and Media was well on the way to solving some of its problems. The situation in Hungary was, however, little changed. ${ }^{\text {viii }}$ The opportunity which was subsequently offered to participate in the TEMPUS project seemed to be a useful way of both reinforcing developments already made in Scotland, of beginning to overcome others, and also of assisting Hungarian 
colleagues to begin to take the same steps forward which the School in Aberdeen had begun to take only a few years earlier. 


\section{Staff development in principle}

To consider how participating in such a project might be a useful form of staff development, it is first necessary to outline the purpose of staff development in Schools of Librarianship and Information Studies, taking the School of Information and Media as a typical example.

Every year, The Robert Gordon University requires each School to review the development needs of its staff individually, and to identify individual and departmental staff development objectives. The overall aim of the University is to develop and maintain the expertise of its staff in line with contemporary professional practice.

In considering the needs of individual members of staff, the objectives are:

- to develop expertise in their major subject areas

- to support the development of their teaching, learning, and assessment skills

- to support the development of their research activities

- to develop their managerial skills

- to promote their professional and academic standing.

Staff development is, however, supported by the University because of its potential contribution towards the achievement of the University's aims. What the University wishes to achieve is:

- to motivate staff to contribute to fulfilling the mission of the University

- to support current and future course development

- to support the development of teaching, learning, and assessment strategies

- to support the development of research activities

- to promote the professional and academic standing of the University and the School.

\section{Purposes of technical cooperation}

How does all this fit in with the aims of technical cooperation programmes?

Typically, technical cooperation programmes focus on a number of activities, such as the exchange of staff, usually intended to assist in the exchange of information and ideas about current practice, and sometimes supplemented by the provision of books, journals and other materials. More established partnerships sometimes develop joint research programmes. Where funding is available, exchanges of students can take place, and detailed examination of the curricula of the participating institutions can lead to jointly taught courses leading to a common award. It is, however, also significant that projects tend to have a fixed duration, determined by the policies of the funding agency or changes in priorities determined by the needs of international diplomacy. Developments initiated in these projects can, in some cases, be left incomplete. In every instance, there follows the challenge of sustaining development and continuing collaboration.

It is important to recognise what almost the partners in technical cooperation projects have in common. In almost all countries, regardless of their wealth or the state of development, there are two noticeable trends in education for librarianship and information science. First and foremost are the attempts being made to revise curricula. As well as continually trying to integrate the latest applications of Information Technology in appropriate parts of their courses, most Schools of Librarianship and Information Studies are also trying to respond to 
other perceived needs for professional skills in their countries. The second general trend is the impact on the education system of national financial circumstances, and/or the fiscal stance of its government. At present, almost universally, politicians seem determined to reduce state expenditure. This affects funding for equipment, for library facilities, for staff development, and the ability to implement change. They are all also trying to raise their profile, both within their profession and institutionally, to secure greater recognition of their efforts and of their significance in contemporary society.

To do this, they need to give careful consideration to the best ways of:

- planning and developing modern curricula, and in conducting related manpower studies

- implementing new teaching methods, and in making the content of new courses relevant

- improving learning resources

- establishing closer contact for both staff and students with all aspects of professional practice and professional education, especially in other countries

- creating partnerships for future collaborative developments. ${ }^{\mathrm{ix}}$

Participation in a well structured and adequately funded technical cooperation programme can provide a foundation for achieving these objectives, although ultimate success depends on continued efforts after the external support has ceased.

\section{Mutual benefits}

Because both the advanced and the less well developed Schools have many common needs, participating in these projects should not benefit one partner alone. What are these benefits, and how do the benefits from technical cooperation activities match the aims of staff development?

Let us first of all consider the needs of the individual.

Table 2: Matching individual staff development needs with inputs from technical cooperation activities

\section{STAFF DEVELOPMENT NEEDS}

- develop subject expertise

- teaching, learning, and assessment skills

- develop research

- develop managerial skills

- professional and academic standing

\section{TECHNICAL COOPERATION INPUTS}

$\Rightarrow$ exchanges between staff

$\Rightarrow$ understanding education in other countries

$\Rightarrow$ establish professional partnerships

$\Rightarrow$ identifying mutual needs and planning shared activities

$\Rightarrow$ contact with practice and education in other countries

Most teachers wish to develop their subject expertise, and find it stimulating to examine what is happening in other countries. Whether they are looking at something more advanced or less advanced than they are accustomed to, it challenges them to think about their own situation, how it can be explained more clearly to their partners or their own students, and how it might be improved. 
Similarly, good teachers are always concerned to improve their teaching skills and the ways in which they encourage their students to learn, and to consider the implications of new ways of assessing their students. Exchanging ideas with colleagues in other circumstances stimulates that process.

Most Schools of Librarianship and Information Studies are small, and staff may not always be able to share their interests with someone in their own institution. They may, however, find someone in the partner institution who has teaching and research interests which are similar to their own.

Teachers all have to be good managers to plan and operate their own courses. Identifying the needs of partner institutions, or planning and controlling a programme of shared activities, and the budget which supports it, can enhance those management skills, and prepare them for greater responsibility.

Finally, technical cooperation programmes can raise the academic and professional standing of individuals in a variety of ways - through the enhancement of their skills, through publication of analyses of the cooperative activities, and through a broader awareness that they have skills which are applicable and valuable beyond the boundaries of their daily existence.

Inevitably, at a time when the pressures on the education system are severe, institutional managements will also expect there to be some clear benefits for the institution. Again, we can find a match between what institutions seek to achieve through staff development and the inputs to that process from participation in technical cooperation programmes.

Table 3: Matching organisational staff development needs with inputs from technical cooperation activities

\section{STAFF DEVELOPMENT NEEDS}

- course development

- teaching, learning, and assessment

- develop research

- generate income

- professional and academic standing

\section{TECHNICAL COOPERATION INPUTS}

$\Rightarrow$ planning and developing modern curricula

$\Rightarrow$ introducing new teaching methods and new subjects

$\Rightarrow$ cooperative research

$\Rightarrow$ development funding

$\Rightarrow$ mutual recognition of curricula

In vocational higher education there is a continual pressure from the employers for staff to keep courses up to date and relevant, and from their institutions to use effective and efficient teaching, learning and assessment processes. Participation in a technical cooperation programme demands that of both partners.

In higher education, there is also always pressure to undertake research. Research, in any form, is an essential underpinning for vocational higher education, maintaining the level of teaching at a standard which is appropriate for higher education, and keeping the curriculum in line with the leading edge of professional practice. Again, technical cooperation projects can present that challenge. At the very least, they require teachers to develop a detailed familiarity with contemporary knowledge in their own specialist field. 
Most technical cooperation programmes attract some kind of funding. For the less wealthy institutions, this may fund developments which otherwise might not be possible. For the institutions in the wealthier countries, it can provide a welcome supplement to their regular budget for staff development, as well as forming a useful political gesture towards the expectation of some governments that higher education should generate income from sources other than the higher education budget.

Finally, the institutions can benefit from mutual recognition of curricula, permitting exchanges of students; articulation between courses so that students can enter with advanced standing; and jointly awarded degrees. Such activity, and the publicity surrounding the project, both serve to raise the profile of the institutions involved.

\section{Staff development in Project 'LISTEN'}

This convergence between the aims of staff development and technical cooperation establishes a framework for assessing the extent to which Project 'LISTEN' has contributed to the achievement of the author's expectation of staff development. The paper will, first, summarise the activities which have been undertaken, and then go on to try to evaluate their impact.

The principal focus of the Project has been the development of modern curricula in our partner institutions, introducing new subjects and new teaching methods, underpinning them through improvements in the teaching equipment. These have been implemented and reinforced through continual exchanges of staff over the last three years, and a smaller number of student exchanges.

\section{Development of individuals}

In reviewing the activities which were undertaken during the Project, a subjective observer would identify a number of activities which contributed quite significantly to the professional development of the individual staff involved. All those involved have developed their subject expertise as a direct result of participating in this Project. Examples range from one very new member of staff who had to quickly learn how to use some complex multimedia authoring software so that she could teach it to Hungarian colleagues, to a more senior member of staff who has had to advise on the foundations of teaching IT. His report on one visit was such a though analysis of the problems in the Hungarian institutions and of the solutions which they might adopt that he came under pressure to undertake a similar review of the School's own provision!

Several staff have been involved in providing an intensive course in Aberdeen for our Hungarian colleagues, and this challenged both experienced and relatively new members of staff to think about how they teach their subject, so that they could explain their approach to colleagues whose needs would be different from those of our regular students. Similarly, in the recent final review of the new courses proposed by the staff of the Hungarian Colleges, the process of evaluating what was proposed inevitably caused those of the Aberdeen staff who were involved to reflect on the validity of what their own School does and how it does it. 
The contacts made through the staff exchanges in Project 'LISTEN' have also been useful in identifying possible future collaborators in research activities, and these will be followed up when appropriate funding sources can be identified. .

Several staff have been involved in the planning meetings for the activities supported by the Project. That has compelled them to think about the strengths (and weaknesses) of the School and their colleagues to determine how they might make the best contribution. More significantly, they had in most cases to manage the follow up planning process, persuading their colleagues to participate, briefing them on what would be expected of them, and coordinating arrangements with colleagues in other participating institutions. This is valuable experience for staff who very shortly afterwards became responsible for managing one of the School's new programmes.

Finally, participation in the Project has contributed to raising the individual profiles of several staff, both professionally and academically, not only on an international basis amongst the partner institutions, but also on a national basis in Britain because of what they were seen to be involved in.

\section{Institutional benefits}

The management of the University will be seeking other benefits to demonstrate that engagement in this activity has been worthwhile. These perhaps need to be put in the context of the mission of the University, which is a commitment:

"to produce versatile and resourceful practitioners who are relevantly qualified for their chosen profession or vocation within an educational environment that fosters innovation, enterprise and an enthusiasm for excellence"

in teaching, learning and research.

The staff development activities implicit in Project 'LISTEN' have clearly made a significant contribution to raising the levels of excellence in teaching and learning - without any significant, direct financial cost to the University. The staff have given their time freely, and have undertaken the Project activities without additional payment and without any significant reduction in their other duties. As a result of their own efforts, and through their awareness of the efforts of the Hungarian partners, it has enhanced their understanding of the need for continuous hard work to implement the programme of change required to maintain the relevance of their teaching in the rapidly emerging 'Information Society', their own professional competence, and the credibility of the University's mission. It has strengthened the School's relationships with a number of other institutions in a way that will enable it to make progress with future research activities funded by the European Commission, which is the best endowed research funding agency to which it has access. There has been a small but measurable cash flow related to the project, and the increased expenditure on air fares may bring a small benefit to the University under the terms of its annual contract with its travel agent. And it has helped to put a 'new University' in a remote part of Europe on the international academic map.

As we look at the School of Information and Media today, its profile seems to be very different from a few years ago. It has eliminated most of its weaknesses, and dispersed the 
principal threat. New strengths are considerable, and new opportunities are becoming available.

Table 4. Current profile of the School of Information and Media

\section{- Strengths}

Highly motivated staff; broad portfolio of courses; adequate equipment; developing student centred learning; growing research activity; European integration; international recognition

\section{- Weaknesses}

Inappropriate funding for the discipline

\section{- Opportunities}

Collaboration with practitioners and with European partners in research and development; collaboration with other academic disciplines in research and course development; the Information Society; breadth of employment for graduates

\section{- Threats}

Development of competing courses

Some part of these changes must be attributed to the energy which has been invested in Project 'LISTEN' and some other technical cooperation projects, to the insights which staff have gained from their involvement, and to the momentum that has been created. This will help to ensure that the School has the internal dynamism which will enable its portfolio of courses to remain ahead of its competitors. It is becoming a living organism, with the ability to learn from and adapt to its environment, and thus to survive ${ }^{\mathrm{x}}$.

\section{Future development}

But, as indicated earlier, technical cooperation programmes can only be considered successful if the impetus for change and development is maintained, and that particularly applies to staff development. Staff who have successfully been encouraged to stretch themselves to achieve more than was previously expected of them will become disillusioned if their new found expertise and self confidence is not continually developed. At the very least, they will need to be encouraged to maintain contact with their partners.

One way in which they may be able to do this, and maintain the impact of the Project is through joint research activities. Clearly, the possibilities for further activities based on topics of mutual interest must be explored. But, where should the impetus for these activities come from? Should it still be led by institutional managers, or should it be left to individual staff to initiate projects, to find and secure the necessary funding, and to manage the activity. In part, the answer to that question depends on personalities, but it also depends on how successful efforts at staff development have been. If they have been successful, then management can be confident not only that there is some certainty of continuing cooperation between the partners, but also that they have staff who have the qualities to ensure that the School will continue to prosper in the future.

In conclusion, the results suggest that participating in projects such as 'LISTEN' makes a contribution to staff development so significant that neither individuals nor institutions can afford not to become involved in future activities of this kind. It remains a matter for concern that so few Schools of Librarianship and Information Studies are involved in technical 
cooperation projects, particularly at a time when the emergence of the 'Information Society' offers a unique, and perhaps final, opportunity to transform the role and profile of the profession. In part, this reflects on the lack of regular contacts between Schools at an international level, but it also appears that their managers in many cases are not confident that they would benefit from participation. This experience of project 'LISTEN' should help to create a greater awareness that these activities do make a major contribution to the development and standing of the participating individuals and institutions, as well as to the development of the profession and the academic community as a whole. Future projects must, however, encompass new partners (including practitioner institutions), to develop a broader base of experience and commitment.

\section{REFERENCES}

${ }^{\mathrm{i}}$ PARKER, J.S. Information consultants in action. Mansell. 1986.

PARKER, J.S. Asking the right questions: case studies in library development consultancy. 1988. London: Mansell.

ii See TANYINE-KOCSIS, Anikó. A szakmai tovabbkepzes lehetosegei egy TEMPUS projekt tukreben [How TEMPUS facilitated staff development] in A konyvtaros es informacios szakemberkepzes megujitasa Renewing the education and training of librarians and information professionals: proceedings of the closing conference of the LISTEN TEMPUS JEP (1994-97); Berzsenyi College, Szombathely, Hungary, 25th to 27th June 1997. 1997. Hungary: Szombathely, Berzsenyi College. pp. 120-126

iii SZERAFIN-SZABOLCSI, Ágnes and TANYI-KOCSIS, Anikó. Teaching Information Sources and Business Information Sources and Services at the Department of Library and Information Sciences at György Bessenyei Teachers’ Training College. Education for Information, 1997 (forthcoming).

iv JOHNSON, I.M. Education for librarianship and information work in Eastern Europe: report on visits sponsored by the European Commission TEMPUS programme, 1992 and 1993. 1993. The Robert Gordon University. (Deposited at E.R.I.C., ref. ED 364 224)

v JOHNSON, I.M. Librarianship and professional education in Hungary. Focus on international and comparative librarianship, 24 (1), 10th May 1993, 14-17.

vi Workshop on education and training of information specialists in Eastern Europe and the Commonwealth of Independent States, Bratislava, Slovakia, November 1994. Final report. Paris: UNESCO, 1995. ref. CII95/WS/10

vii JOHNSON, I.M. Multiple levels of education and training for library and information work in Hungary: report on a visit, 23 April - 7 May 1988. College of Librarianship Wales, July 1988. Unpublished report submitted to the British Council.

viii JOHNSON, I.M. Librarianship and professional education in Hungary. Focus on international and comparative librarianship, 24 (1), 10th May 1993, 14-17.

ix JOHNSON, I.M. Recent trends in cooperation between schools of librarianship and information studies in Library and Information Science - parameters and perspectives (essays in honour of Prof. P.B. Mangla); $\underline{\text { edited }}$ by R.G. Prasher. 2 vols. 1997. India, New Delhi: Concept Publishing Company. Vol.1 (Library and Information Science: basic), pp. 75-80. ISBN 8170226341 (Volume 1).

$\mathrm{x}$ De GEUS, A. The living company: habits for survival in a turbulent business environment. 1997. U.S.A., Boston: Harvard Business School Press.

\section{AUTHOR}

Ian Johnson has been Head of the School of Information and Media at The Robert Gordon University, Aberdeen, Scotland since 1989. Previously he was in charge of industry liaison and continuing education programmes at the College of Librarianship Wales; Assistant to the British Government's Advisers on library matters; and an operational manager in public libraries. He was Chairman of the International Federation of Library Association's (IFLA) Section on Education and Training from 1991 to 1993, and Chairman of the Professional 
Board of IFLA from 1993 to 1995 . From 1993 to 1995 he was also Chairman of the (British) Library Association's Personnel, Training and Education Group. He is currently a member of the Council of The Library Association, and of the Editorial Board of Education for Information; and Chairman of the Heads of Schools and Departments Committee of BAILER: the British Association for Information and Library Education and Research.

An earlier, shorter version of this paper was presented as: Staff development: a Western perspective. in "Renewing the education and training of librarians and information professionals", the closing conference of the 'LISTEN' TEMPUS Joint European Project, Berzsenyi College, Szombathely, Hungary, June, 1997. 